ARt. XXIV.-Structure of the Upper Cretaceous Turtles of New Jersey: Lytoloma;* by G. R. Wreland. (With Plates V-VIII.)

In 1865 Leidy described as Chelone sopita certain chelonian marginals from the Upper Cretaceous or Greensand of Tinton Falls, Monmouth county, and several others from Mullica Hill, Gloucester county, New Jersey. One of these specimens, including three left marginals and part of a fourth, was figured as the type.t

In 1870 Cope established his genus Lytoloma, at the same time making a not very clear reference of Leidy's Chelone sopita to both Propleura and Lytoloma. $\ddagger$ The type species of the latter genus, $L$. angusta, as tigured, is seen to consist of a single marginal and fragmentary lower jaw with a remarkably long symphysis. Bearing in mind, however, the closely associated manner in which the numerous forms from the New Jersey Greensand occur, there is at present no positive proof that this marginal and lower jaw belong to the same individual or even species, although both these possibilities are probable.

The close resemblance of the lower jaw of Lytoloma to that of Chelone crassicostatum (Owen, 1849) \& was noted by Cope. The latter type consists of a skull and lower jaw articulated in normal position, and is a rarely perfect specimen. It was more completely freed from its matrix, - a hard septarian nodule from the London Clay (Lower Eocene), and further illustrated and described, by Lydekker, in 1889, as Lytoloma crassicostatum.\| Its generic relationship to $L$. angusta of the New Jersey Greensand, and to the lower jaw from the Landenien (inférieur) of Erquellinnes, Belgium, first described by Dollo as Pachyrynchus, and later referred to Euclastes, ${ }^{* *}$ appears to be unquestioned.

* The first paper of this series, on Adocus, Osteopygis, and Propleura, was published in this Journal, Feb., 1904. The third paper will be on Agomphus.

+ Cretaceous Reptiles of the United States, Smithsonian Contr. to Knowl., vol. xiv, 1865 , pl. xix, fig. 5 .

$\ddagger$ Extinct Batrachia, Reptilia and Aves of North America, 1869, pp. 140, 145 : and pl. xi, figs. $1-1 \mathrm{~b}$.

Fossil Reptilia of the London Clay, Part I. Chelonia, Paleontographical Society, p. 27, pl. xi.

$\|$ On a skull of the Chelonian genus Lytoloma. Proc. Zool. Soc., London, 1889 , pls. vi, vii.

ๆ Les Cheloniens, Landeniens (Eocène inférieur) de la Belgique, Bull. Musée Roy. d'Hist. Nat. de Belg., t. iv, No. 3, Juill, 1886.

** With reference to the priority and synonymy of the species here discussed, it is necessary to note that the skull Euclastes platyops Cope was first mentioned in 1867 ; hence Euclastes antedates Lytoloma two years. Moreover, according to Dollo (Sur le Genre Euclastes, Ann. Soc. Geol. du Nord., t. xv, p. 114, Mars, 1888) Euclastes includes Chelone Owen, 1841; Lytoloma Cope, 18i1; Glossochelys Seeley, 1871; Puppigerus Cope, 1871; Pachyrynchus Dollo, 1886 ; Erquellinesia Dollo, 1887. But later Boulenger and Lydekker (Geol. Mag., Dec. 3, vol. iv, p. 270, 1887), pointed out that Euclastes is preoccupied; thus the later name Lytoloma becomes valid. 
It is thus seen that the cranial characters of Lytolome angusta Cope are inferentially known and point conclusively to a position in the Cheloninæ, although as yet no adequate description of a Lytoloman carapace from the Greensand of New Jersey has been given. It is therefore of distinct interest to find that the Yale specimen No. 625 proves to be a fairly complete carapace, with marginals so distinctly like those of L. angusta as to indicate their specific identity. Moreover, the rather close relationship to Propleura, and the various primitive characters present, add to our knowledge of the early marine forms, and bring us a step nearer to the actual lines of descent of existing marine.turtles from littoral forms. While not known to have survived beyond the Eocene, the Lytolomas show by their structure that they were not more than generically removed from the existing genus Chelone. Before passing on to the description of the carapace, however, it will, because of the extended synonymy just reviewed, the considerable number of years since the collection of the materials from New Jersey, and the fragmentary condition of many of the specimens, be necessary to note briefly the evidence as to accompanying cranial character's.

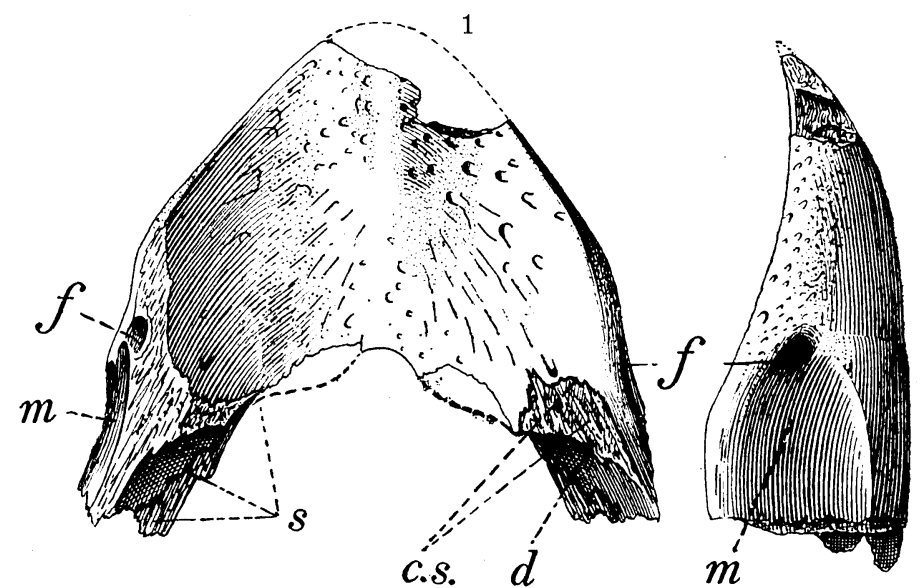

Figure 1.-Lytoloma angusta Cope. Superior and lateral view of Dentalium. $\times \frac{4}{5}$. (Y. S. 913, from Upper Cretaceous Greensand of Hornerstown, New Jersey. c. s., coronoid suture and sutural surface; s, splenial suture and sutural surface ; $d$, dental foramen (orifice slightly arched over) $f$, nutrition foramen (for mandibular branch of jugular vein-Bojanus); $m$, masseteric fossa (insertion of masseter muscle).

\section{The Lower Saw.}

Evidence of the specific association of lower jaws and marginals of the Lytoloma angusta form is not abundant in the Yale collections, though fairly conclusive. A dentalium which is accompanied by a fragmentary but characteristic marginal is 
shown in figure 1. Several more or less isolated jaws of the same form attain about double the size of that illustrated.

The relative width of the lower jaw of Lytoloma is much greater than in the living Chelonians. Its further peculiarities are mainly to be observed in the dentalinm, notable for its remarkably long symphysis and very large pits for the insertion of powerful masseter muscles. These specialized features primarily suggest a conchifragous habit.* The massive imperforate palatal surface described below also strongly supports the view that these Lytolomas had become littoral conch-eaters, finding their home and an abundant supply of mussels and other "shell fish" on the New Jersey Cretaceons shore lines.

\section{The Cranium.}

With the exception of $L$. (Euclastes) platyops Cope no further Lytoloma crania from the Upper Cretaceous of New Jersey have been figured. The only specimen in the Yale collection referable to the genus is an isolated anterior portion of a skull, which is, however, in a wonderful state of preservation, as shown in the accompanying text-figure $2(\mathrm{~A}, \mathrm{~B}$, and $\mathrm{C})$. There is no means of now determining with certainty whether or not this specimen is a Lytoloma angusta. It is quite possible that the lower jaw pertaining to it had a somewhat differently shaped coronoid region than that of $L$. angusta. Rather than erect a new species on such slender evidence, it may suffice to refer to this rare and interesting specimen by number when comparing its characters with those of other forms. With L. platyops Copet this comparison is as follows:-

Lytoloma (Euclastes) platyops Cope. $\quad$ Lytoloma, Yale specimen No. 913a.

1. "Maxillaries and palatines separated throughout by the prolonged vomer."

2. "Posterior nares opposite palatal front margin of orbits" (? ?).

3. "Premaxillary margin projecting beak-like:" alveolar face little concave.

4. "Vomer forming a central ridge."

1. Maxillaries and palatines probably separated throughout by elongate vomer.

2. Internal narial opening well back from both the lower (palatal) and the upper (orbital) anterior border of the palatines.

3. As in L. platyops ; that is, premaxillaries projecting more than in the Chelonidæ. but not forming a projecting and decurved beak as in either Chelydra or Archelon.

4. Outer (or palatal) surface of vomer flat anteriorly but raised between the palatines.

5. Floor of nasal meatus perforate for hook of mandible.

6. "Nostrils superior behind the short projecting beak (not borne on a projecting muzzle)."

5. Floor of nasalmeatus imperforate and very thick.

6. As in L. Platyops (not Bothremys).

* Dollo, Première Note sur les Cheloniens landeniens (éocène inférieur) de la Belgique, Bull. Musée Roy. d'Hist. Nat. de Belg., t. iv, No. 3, p. 138, 1886.

† Loc. cit., p. 148 . 
In both the above skulls (borrowing further from the description of L. platyops, as given by Cope), the descending portion of the prefrontal is very wide, and equal to the width of the maxillary outside the small lachrymal foramen. Inter-

$\mathrm{A}$

2

$\mathrm{B}$

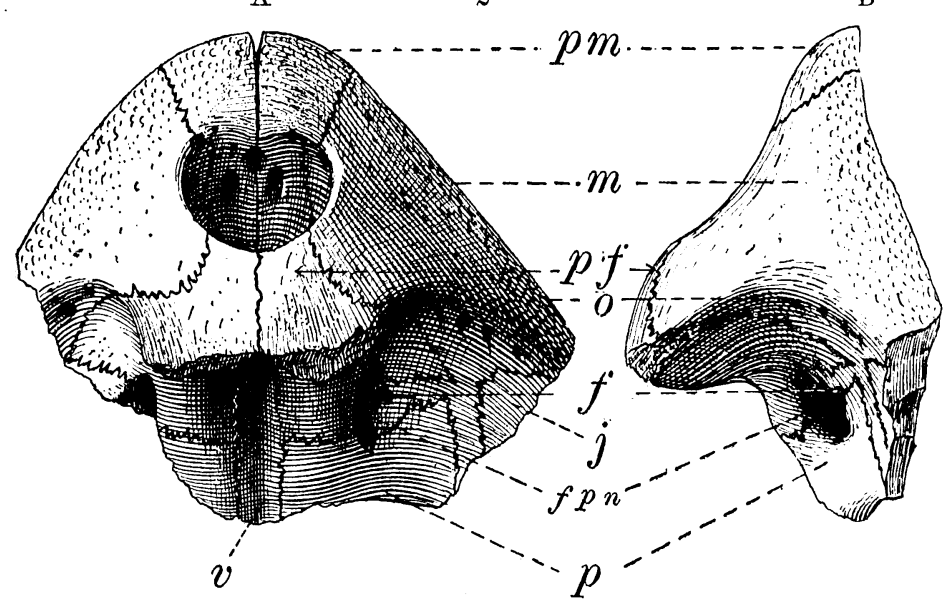

$\mathrm{C}$

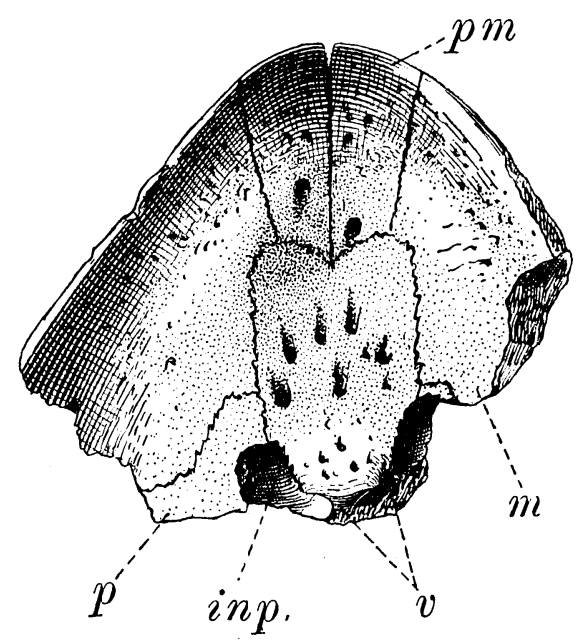

Figure 2.-Lytoloma angusta? Anterior portion of cranium. $\times \$$. Yale specimen 913a. From the Upper Cretaceous of Hornerstown, New Jersey.

A, superior,-B, right lateral,-C, palatal view.-pm, premaxilary; $m$, maxillary ; $p f$, prefrontal ; $o$, anterior border of orbit; $f$; foramen (alveolare superius? ?) ; fpn, foramen palatino nasal ; j, jugal ; $p$, palatine ; $v$, vomer ; inp, internal narial passage (the vomero-palatine wall being partly broken away). 
nally the columns of the prefrontals converge below nearly to an acute angle and are directed forward, also much backward in Lytoloma (Yale specimen No. 913a), thus forming a strong internal base on the vomer. They restrict the nasal meatus, leaving its diameter less than that of the columns.

The internal nares in the present specimen open far back; but the long, broad, and massive romer is fairly complete, and it is not likely that the palatines closed in behind it to further roof the narial passage. If so, herein may lie a marked difference from the still more specialized Eocene Lytolomas from the London Clay and the Landenien inférieur of Belgium. In describing the skull of Lytoloma crassicostatum Owen, Lydekker says: "one of the first points which strikes the observer [on comparison with Thalassochelys] is its extreme shortness, the width at the widest part of the temporal arch being exactly equal to the length from the occipital condyle to the muzzle; whereas in the Loggerhead the former diameter is considerably less than the latter, whilst in Chelone the difference between the two diameters is still greater. Still more noticeable is the backward position of the posterior nares, which are situated at a point one third the distance from the condyle to the muzzle, as indeed is mentioned in M. Dollo's description of the Belgian specimens. In that description it is, however, stated that the boundary of the posterior nares is formed by the development of the palatal plates from the pterygoids. So far, however, as can be seen from the present specimen, it would appear that this border is really constituted by the palatines, since on either side there seems to be a distinct suture separating the bones forming the border of the posterior nares from the uncloubted pterygoids. Looking at the arrangement of the palatines in the Loggerhead, it would seem much more natural that these should be prolonged backwards, rather than that the ptersgoids should assume the condition assigned to them by M. Dollo. In either case the vomer is excluded from the posterior nares, but its position anteriorly is not shown in this specimen." (It is obscured by the lower jaw which is in place.)*

\section{The Carapace and Plastron. .}

The specimen (Yale Catalogue, No. 625) on which the following description is mainly based was received from the West Jersey Marl Company, May 1, 1869. It is from the old, long unworked marl pit, one and one-half miles east of the rillage of Barnsboro, Gloncester county, New Jersey. Willows, holly, pine, etc., now grow scatteringly over this area of former excavation some thirty acres in extent, which has yielded so many other interesting fossils, among them the remarkably tine carapace and plastron Osteopygis Gilbi. 
The recovered portions of the present specimen, shown in detail by the stippled areas in Plate VIII, consist of $(a)$ the third, fifth and sixth neurals; (b) the antero- and postero-pygal; (c) the pleuralia of the right side less the free-rib tips, but with the inner or neural borders of all but the second distinct; $(d)$ the first to the fifth pleurals inclusive of the left side, the freerib tips of the second and fifth being present, also a fragment of the seventh pleural, as indicated by its form and the posterolateral furrow of the fourth vertebral horn-shield which crosses it; $(e)$ the fourth to the seventh inclusive, and the ninth marginals of the right side, and the fourth to the eleventh marginals inclusive of the left side, with the anterior half of the pygal marginal. There are also some fragments of the accompanying plastron, which, although too incomplete to permit the exact restoration of any of the plastral elements, indicate a plastral form even more reduced than, but otherwise much like that seen in Osteopygis and Propleura.

With the exceptions mentioned, all parts of the carapace, as far as recovered, are uncrushed and but little broken. As sent to the museum, they were dissociated, but the sutures are well preserved and almost withont exception interlock in their normal position, so that it is possible to determine these elements, as well as the general form of the carapace. The fortunate presence of the third neural, with both the adjoining third pleurals as well as two rib tips of the left side, leaves no doubt as to the width of the carapace. Moreover, the borders of the missing second, fourth, seventh, eighth, and ninth neurals are indicated exactly, and those of the first neural approximately. The anterior sutural border of the first left pleural being complete, there can be little doubt but that the nuchal had approximately the outline indicated in Plates VI-VIII. The length of the missing three anterior marginals can only be inferred, but must be nearly that shown in ontline.

With regard to the general form of the marginals and of the posterior neurals in the present genus, and in Osteopygis and Propleura, figures $3-6$ in the text afford data for exact comparison. Taken in conjunction with the facts already given, they require little further description. It may only be noted that the specimen represented in figure 5 shows a diminution of the posterior neurals more marked than that in Osteopygis Gibbi, while the condition in Propleura, tigure 6, is more like that of the present form.

As indicated in Plates VI and VII, the horn-shield furrows are all distinct and rather broad. The carapace is of suborbicular outline, being broadest across the posterior end of the fifth neural. In this respect it is somewhat intermediate between cordate forms like those of the existing Cheloninæ 
and the Osteopyges, which are broadest across the anterior end of the sixth neural. In the present more primitive turtle the cordate form of the Chelonine carapace is beginning to appear, the swinging back of the eighth rib into a pit of the eleventh marginal, and the consequent leaving of the tenth
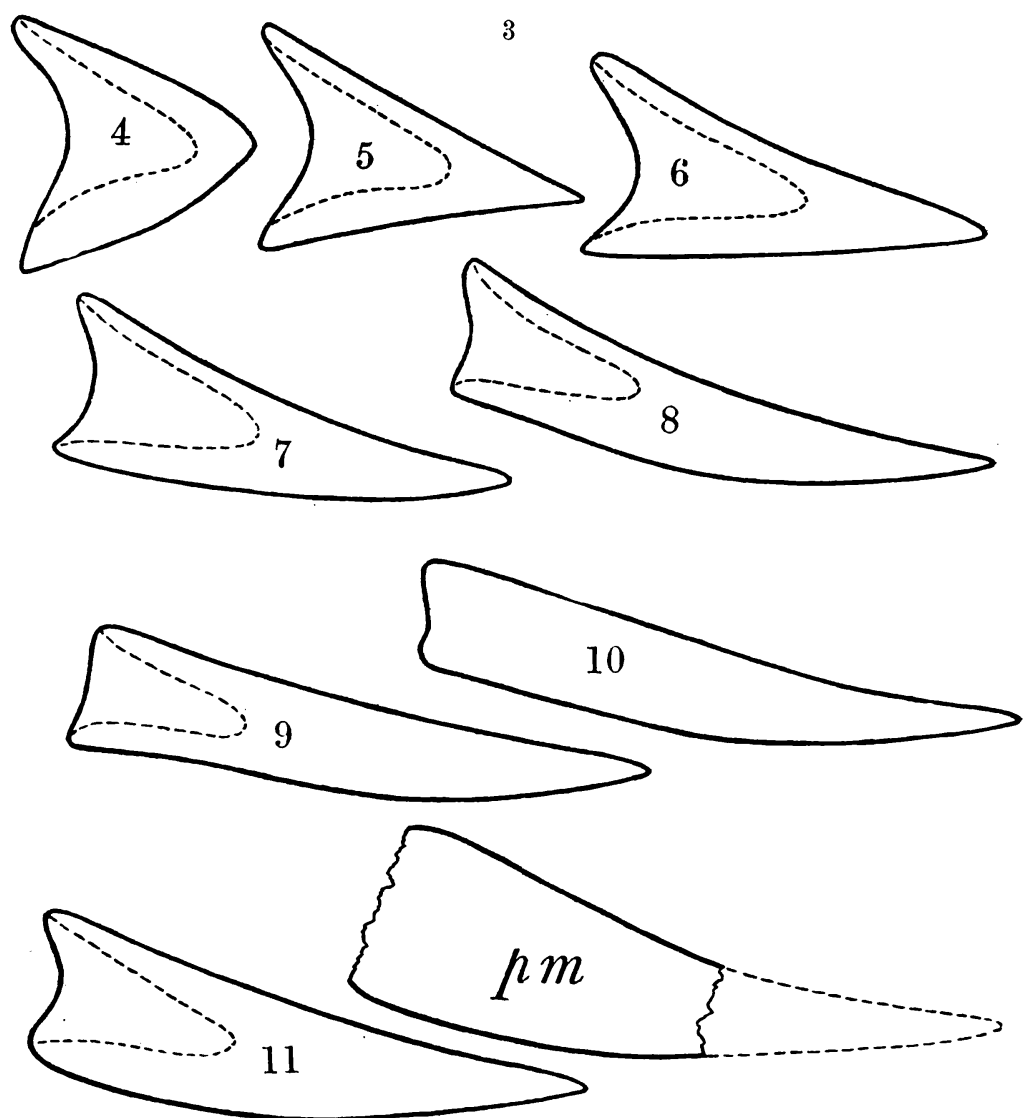

Figure 3. - Lytoloma angusta Cope (Yale specimen 625). Natural size. Vertical middle transverse section through the 4-11, and pygal ( $p$ m) marginals. Respective rib pits in dotted outline.

marginal without a supporting rib, as in Chelone, having already occurred. Compare plates V and VI. In Osteopygis $G i b b i$ the femur is longer than the humerus, and from general comparison it may be argued that in the present species of Lytoloma the femur is relatively shorter than in Osteopygis, but not so shortened as in the existing marine turtles. This intermediate development is an important point. 
In addition to the fragmentary portions present, the general form of the plastron is in part indicated by the marginals. The digitations of the antero-external limb of the hyoplastron projected into several small shallow pits in the lower border of the posterior half of the fourth and the anterior half to threefourths of the fifth marginals, thus forming a dactylate junction

4

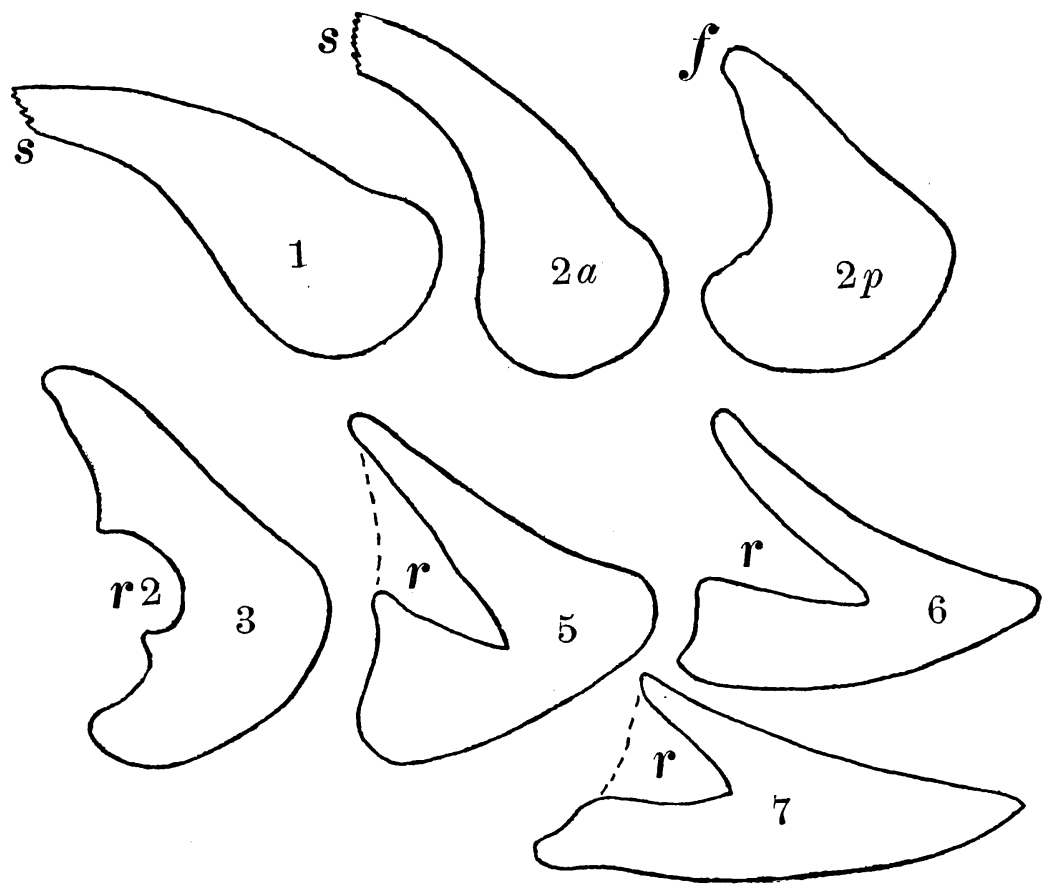

Figure 4.-Propleura borealis Wieland (type). $\times \frac{2}{3}$. Vertical, middle, or end transverse sections of marginals for comparison with the marginals of Lytoloma shown in figure 3.

$1,3,5,6,7$, middle sections numbered respectively ; $2 a, 2 p$, anterior and posterior end outline (or section) of second marginal; $s, s$, inner border of first and second marginal (uniting by suture to first pleural and not free as in Lytoloma); $f$, free border; $r 2$, claw-shaped furrow in third marginal for reception of second rib; $r, r, r$, rib pits in 5-7 marginals for reception of respective, $i$. e. $3-5$ ribs.

6.5 to $8^{\mathrm{cm}}$ in length. This is a distinctly shorter junction than in Osteopygis, in which the outer hyoplastral limb extends forward to the second marginal, and is about equal in extent to that seen in Eretmochelys. No distinct pits for the reception of the outer digitations of the hypoplastron exist in the fossil at hand. In the Osteopyges, these are present for both limbs of 
the plastron, marginals 2 and 8 being deeply pitted for the extreme ends of the hyo- and hypoplastron, respectively, as explained in the description of $O$. Gibbi and Propleura. In

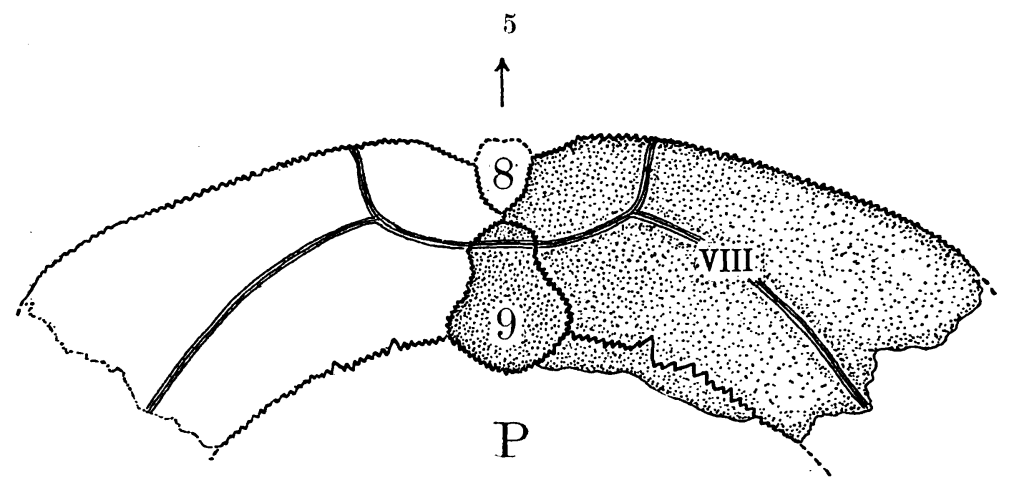

Figure 5.-Osteopygis sp. (Yale specimen 908). $\quad \times \frac{1}{2}$. Right eighth pleural with the ninth neural and a portion of the antero-pygal $(P)$ attached. Hornshield borders of fourth and fifth vertebralia and fourth costal horn-shields distinct and shown in triple line. (Thickness of nemal is $\cdot 7 \mathrm{~cm}$.)

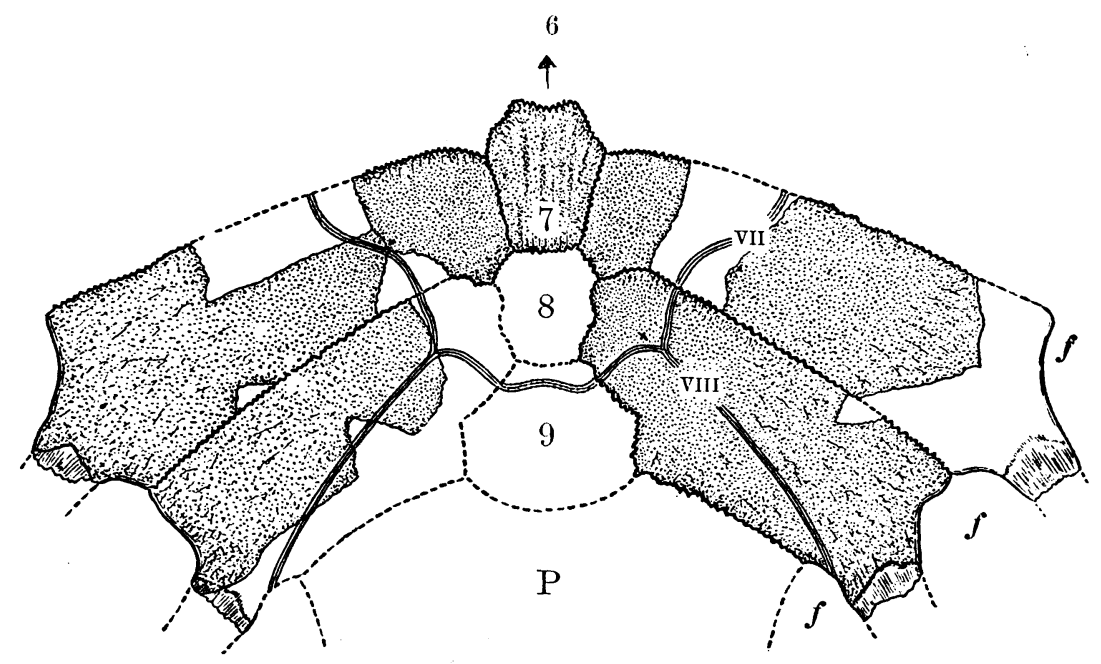

Figure 6. - Propleura sp. (Yale specimen 559). $\times \frac{1}{8}$. Right and left seventh and eighth pleuralia and seventh neural with borders of the fourth and fifth vertebral and the fourth costal hom-shielas distinct and shown in triple line. Stippled portions only preserved. 7-9, neuralia; VII, VIII, pleuralia: $\mathrm{P}$, antero-pygal ; $f, f, f$, the three posterior pleuro-marginal fontanelles. (Thickness of pleuralia at sutural edge $\cdot 3-\cdot 5 \mathrm{~cm}$.) Barnsboro, New Jersey.

the living Cheloninæ, the marginal pits for the plastral digitations are indistinct. Hence, Lytoloma is also intermediate in this respect. 
Adocus, Osteopygis, Lytoloma, and Chelone thus virtually form a series passing from a strong cleido- to a weak dactylósternal plastral junction. The large anterior and posterior plastral foramina and the elongated entoplastron, however, are distinct departures from such a plastron as that of Adocus, leading to the plastral form seen in living sea turtles.

\section{Synopsis of the Characters of Lytoloma.}

Cranium.-Agreeing in most characters with the existing Cheloninæ, but specialized for a conchifragous habit; short, very broad, with external nares directed as much upward as forward. Vomer large and heavy; internal nares roofed over back of vomer by union of palatines in Eocene species (Lydekker and Dollo), but probably not in New Jersey Upper Cretaceous forms; palatal surface perforate for lower jaw in $L$. (Euclastes) platyops Cope, heavy and imperforate in Lytoloma (Yale specimen No. 913a = L. angusta?).

Lower Jaw.-Short and broad, with a very long symphysis, and wide and deep lateral pits for the attachment of heavy masseter's.

Carapace.-Suborbicnlar in ontline, with wide and persistent pleuro-marginal fontanelles; composed of 51 bony plates with the boundaries of the (38) horn-shields distinct, the numerical agreement thus being complete in Osteopygis, Propleura, and Chelone. Marginals 11 pairs, narrow anteriorly, but increasing in breadth to the eleventh, which is nearly as broad as long, with outer borders forming an evenly continuous curve to the eighth marginal, beyond which the carapace is more and more emarginate at the ends of the marginals, upper and nether surfaces of equal area, inner surface a shallow rounded furrow; both outer surfaces of fourth marginal nearly flat, with slight concavity of the upper surface and convexity of the lower surface beginning with the fifth and increasing to the eleventh, supported by rib tips only, and upper inner borders bounding the series of large pleuro-marginal fontanelles; rib pits deep and of round to elliptical section, those for the second to the eighth ribs being borne posteriorly on the third to ninth marginals inclusive, the tenth marginal ribless and the eleventh supporting the ninth rib anteriorly, as in Chelone. Nuchal large and broad. Neuralia (9) without marked tendency to the suppression of any of the final members of the series, as in Adocus and Osteopygis. Antero- and postero-pygal as in Chelone; surface of the plates smooth, not pitted, and as in the living Chelonians.

Horn-shields.-(38 in number) agreeing numerically with those of Chelone. Vertebralia broader than long.

Plastron.-Much as in Osteopygis, but with a narrower 
bridge (as indicated by fragmentary portions accompanying Yale specimen No. 625, and by marginals 4 and 5).

Limbs.-Little known; humerus and femur thalassoid, and of nearly equal development.

Habitat.-Infralittoral. Habit.-Conchifragous.

Range.-Upper Cretaceous and Lower Eocene of Europe and America.

\section{Systematic Position of Lytoloma and of Osteopygis.*}

Where shall we place Lytoloma, which in common with Osteopygis and Propleura has a reduced and somewhat Chelydra- or Staurotypus-like plastron, and a distinctly Chelonelike carapace? It is my belief, based on certain somewhat fragmentary fossils which it is proposed to illustrate later, that in the New Jersey Upper Cretaceons there were already present forms more nearly related to Chelone than is Lytoloma, although as Dollo well suggests such are far rarer than has been assumed. Second, the free tenth marginal of Lytoloma indicates that the swinging back of the ninth rib (or eighth and ninth ribs), thus leaving the ninth or tenth marginal, as the case may be, without rib-support, took place early, and was correlated with the shortening of the femur and the development of heavy front flippers. Third, it appears that Osteopygis and Propleura belong to a side line, with long and still chelic femora, which never accomplished the rib change just mentioned and did not survive; and fourth, Lytoloma originally sprung from this side line. If so, the latter genus developed by parallelism a carapace which, with the skull (that of Osteopygis being yet unknown) and the thalassoid humerus, brings it so near to Chelone as to make necessary the inclusion of both these genera in the same subfamily.

Having settled this point, the question remains as to whether the two genetic groups containing Osteopygis, Propleura, and Lytoloma on the one hand, and the living members of the Cheloninæ and their more direct ancestors in the other, shall be included in the same subfamily. Osteopygis, the most primitive of all the forms in question, is removed from Chelone by its less modified limb structure, with all or nearly all the claws present; by its less reduced marginals, consecutively rib-

* In my first paper on the Upper Cretaceous Turtles of New Jersey (this Journal, vol. xvii, Feb., 1904), the opinion was tentatively expressed that Osteopygis and Propleura might best be separated in a distinct family, namely Cope's Propleuridæ, but the utmost degree of separation any one might suggest, now that Lytoloma has been more closely considered, would be as a subfamily, - the Propleurinæ. The position now assigned to these forms is virtually that given them in a provisional classification of marine turtles, proposed earlier (this Journal, vol. xiv, p. 108, 1902), and to which I shall as yet adhere, although recognizing with Dollo the great difficulty, if not impracticability, of satisfactorily dividing the Cheloniidr into subfamilies in the present imperfect state of our knowledge of the group. 
supported; by the absence of pleuro-marginal fontanelles and the nether articular process of the nuchal, and finally by its mere Chelydra-like pelvis and earlier type of plastron. Doubtless there are also cranial differences. There is, therefore, between Osteopygis and Chelone, when considered alone, a very distinct structural interim such as might well characterize two subfamilies. Lytoloma, however, is so exactly intermediate that taken with other forms, existing and extinct, there exists a nearly continuous morphological series, passing by simple generic or even lesser stages from the most specialized existing Cheloninæ back to Osteopygis. In fact the greatest hiatus remaining unbridged appears to be the ribless ninth or tenth marginal, as seen in Lytoloma and existing forms. I am at a loss to surmise if this condition was due to a slowly effected change, or was suddenly developed after the appearance of pleuro-marginal fontanelles in the early line, giving rise to the two genetic groups mentioned. In either case it must have been, as already hinted, correlated with femoral shortening and the development of strong front flippers, and is scarcely to be considered as of more than generic value. If a separation into two subfamilies were made, it would have to be based mainly on this feature, as furnishing the only sharp distinction.

The final conclusion must be that Osteopygis and Propleura can be placed in a separate subfamily, the Propleurinæ, on genetic grounds, but that further discovery may bring them very near if not into the Cheloninæ. Moreover, as has been seen, these forms, though not apparently forming a closed series, permit the statement that Osteopygis was no more than generically separated from some strongly web-footed littoral turtle, which was the true ancestor of the existing Cheloninæ.

The facts given in the present and preceding papers on the Upper Cretaceous turtles of New Jersey, as well as in my paper on Toxochelys, indicate the manner in which the marine turtles have been derived from generalized land forms, together with their line of descent. Aside from the carpal and tarsal changes involved and as yet but meagerly illustrated by fossil forms, the most interesting future discoveries will be the ancestral, littoral, and fluviatile Osteopygoid tortoises.

\section{Measurements of Iytoloma.}

(A) The dentalium of Lytoloma angusta (Yale specimen No. 913.) Üncrushed.

Width (measured from outer extremities of the coronoids) ........

Distance (on median line) of hook from anterior ends of the coronoids . . . . . . . . . . . . . . . . . . 4.7

Length of median symphysis . ................ $4 \cdot 2$

Greatest vertical depth of median symphysis ...... $1 \cdot 1$ 
(B) Anterior portion of the skull of Lytoloma sp. (Yale specimen No. $913 \mathrm{a}=L$. angusta?.) Uncrushed.

Length of palatal surface of vomer . . . . . . . . . . $3 \cdot 3$ Width "6 "6 "6 ...........

Length of palatal surface of premaxillary _. . . . . . . $2 \cdot 7$ Greatest width of palatal surface of premaxillary _. $1 \cdot 0$ Greatest thickness of vomeral partition between the nares ... . . . . . . . . . . . . . . . . . . . . . $1{ }^{1}$

(C) The carapace of Lytoloma angusta. (Elements uncrushed and disarticulated. Yale specimen No. 625.)

Length (estimated to within one or two centimeters) $58^{\circ}$ Breadth (greatest, as measured across anterior end of fifth neural). $53 \cdot$

\section{(1) Bony Plates.}

(a)

Exact length on outer edge of

Nuchal

1st marginal....

$2 \mathrm{~d}$

"3 6 ...

4th 6 "6

5th “ $\quad . .$.

6 th 6 "...

7th "6

8th " " ...

9th "

10 th

$11 \mathrm{th}$

Pygal carapace.

$\cdots$
$\cdots$
-
$5 \cdot$
$7 \cdot 2$
$7 \cdot 2$
$8 \cdot$
$8 \cdot$
$8 \cdot 2$
$7 \cdot 5$
$7 \cdot 8$
$4 \cdot 7$

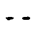

-

$-$

$5 \cdot 5$

$7 \cdot 2$

$7 \cdot 2$

8 .

8 .

$8 \cdot 2$

$7 \cdot 5$

$7 \cdot 8$

$4 \cdot 7$
Length on median line.

Nuchal

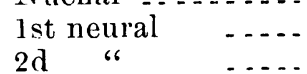

$2 d$ "

$3 \mathrm{~d}$ "

4 th "6

5 th "

6 th "

Tth " $\quad \ldots .$.

8 th "6

9 th “

Antero-pygal .....

Postero-pygal ..... .

Marginalo- "6

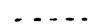

$-\cdots$

(-..-

- ....

- - .

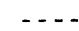

$(5 \cdot 0)$

$(5 \cdot 0)$

$4 \cdot 4$

$(5 \cdot 5)$

$4 \cdot 1$

$4 \cdot 1$

$(3 \cdot 1)$

$(3 \cdot 0)$

$(3 \cdot 5)$

$3 \cdot 7$

$6 \cdot 0$

$6 \cdot 0$ (b)

Width along groove of horn-shields.

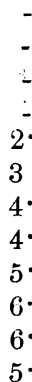

- -

-

$2 \cdot 5$

36

$4 \cdot 3$

$4 \cdot 8$

$5 \cdot 6$

6 .

6 .

$5 \cdot 5$

$(5 \cdot 5)$

Greatest width.

$(4 \cdot 0)$

$(5 \cdot 0)$

$4 \cdot 4$

$(4 \cdot 2)$

$4 \cdot 1$

$3 \cdot 4$

$(3 \cdot 3)$

$(2 \cdot 7)$

$(3 \cdot 0)$

8.0

$(8 \cdot 0)$

$4 \cdot 7$ (c)

Greatest thickness.
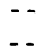

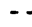

$2 \cdot 4$

$2 \cdot 3$

$2 \cdot 2$

$1 \cdot 8$

$1 \cdot 5$

$1 \cdot 3$

$1 \cdot 3$

$1 \cdot 5$

$1 \cdot 8$

Thickness.

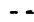

$\cdots$

$-$

$\cdot 6$

$\because 7$

$\cdot 7$

-

-.

1.

$1 \cdot \overline{8}$ 


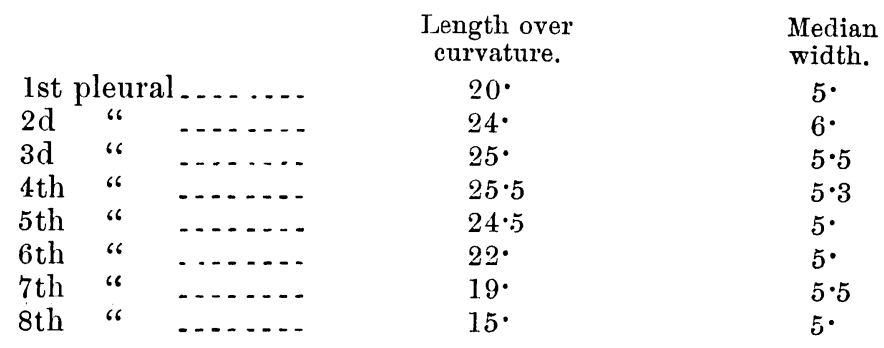

(The large pleuro-marginal fontanelles are approximately onethird the length of the pleurals which respectively bound them.)

(2) Horn-shields.

Length on median line of carapace.

Greatest breadth.

Nuchal............

lst vertebral

3d "

4 th 6 " 610.

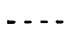

-...

$10^{\circ}$

$11^{\circ}$

$11 \cdot 4$

-...
11.

$14 \cdot 5$

$13 \cdot 5$

$15^{\circ}$

Length of fifth-eleventh marginal horn-shields, respectively, measured along outer border of carapace :-6.5, $7 \cdot 5,8 \cdot 0,8 \cdot 5,8 \cdot 0$, $8 \cdot 0,7 \cdot 5$.

\section{LETTERING OF PLATES V-VIII.}

(a) Bone Plates:- $N$, Nuchal ; $1-9$, Neuralia ; $A$, Antero-, $P$, Postero-, $M$, Marginal-Pygal ; $I-V I I I$, Pleuralia ; $M 9-M 11$, 9th-11th Marginals ; $s$ (in Plate V), Supernumerary neural.

(b) Horn Shields:-n, Nuchal ; v, v, v, v, v, 1st-5th Vertebralia ; $c, c, c, c$, 1st-4th Costalia; $S$ (in Plate V), Supernumerary vertebral ; 10-12, Marginalia ; $f, f, f$, Pleuro-marginal fontanelles.

Yale University Museum, New Haven, Conn. 


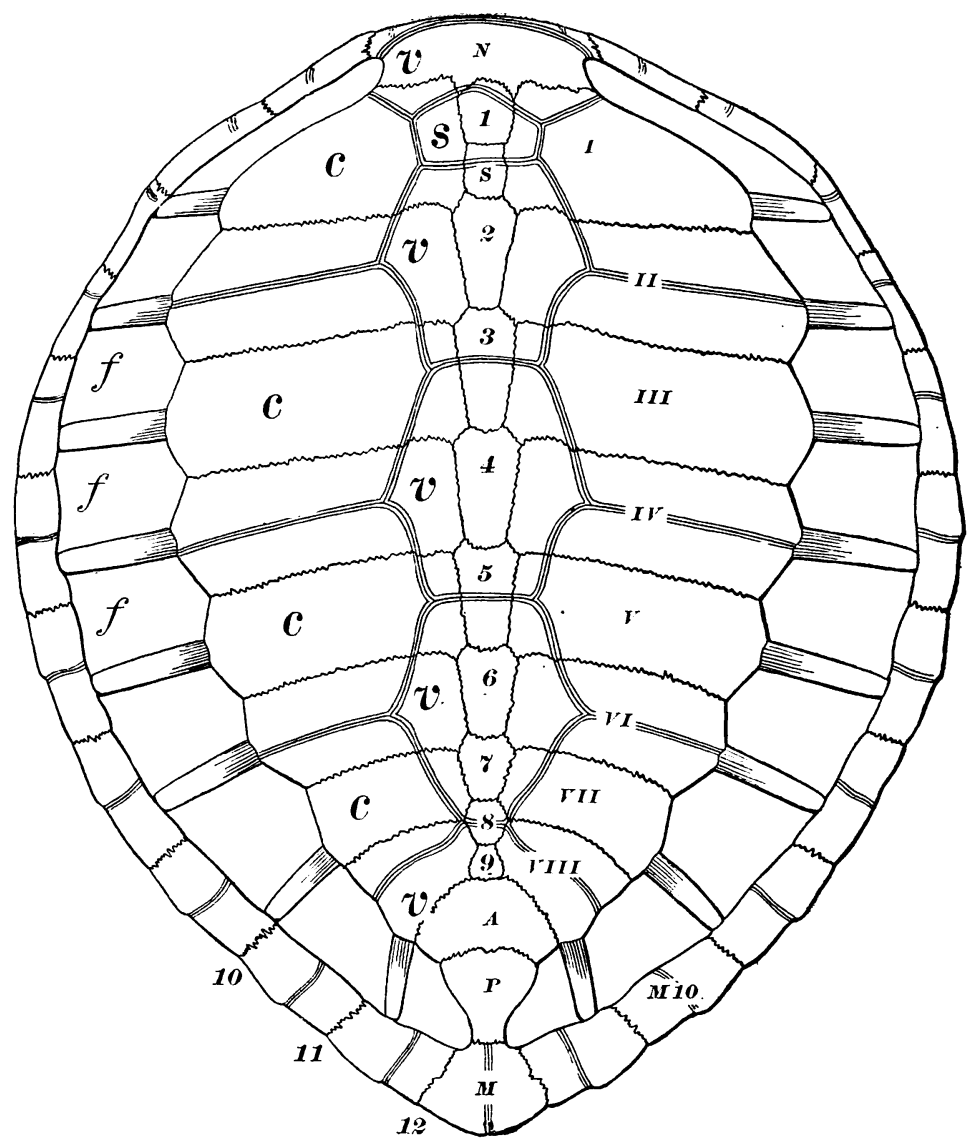

Carapace of Chelone mydas L. (var. or sp. nov.) Southern Atlantic coast of the United States. A young specimen $\times \frac{1}{4}$. Free borders in smooth. sutures in zigzag, and boundaries of the horn-shields in triple line. 


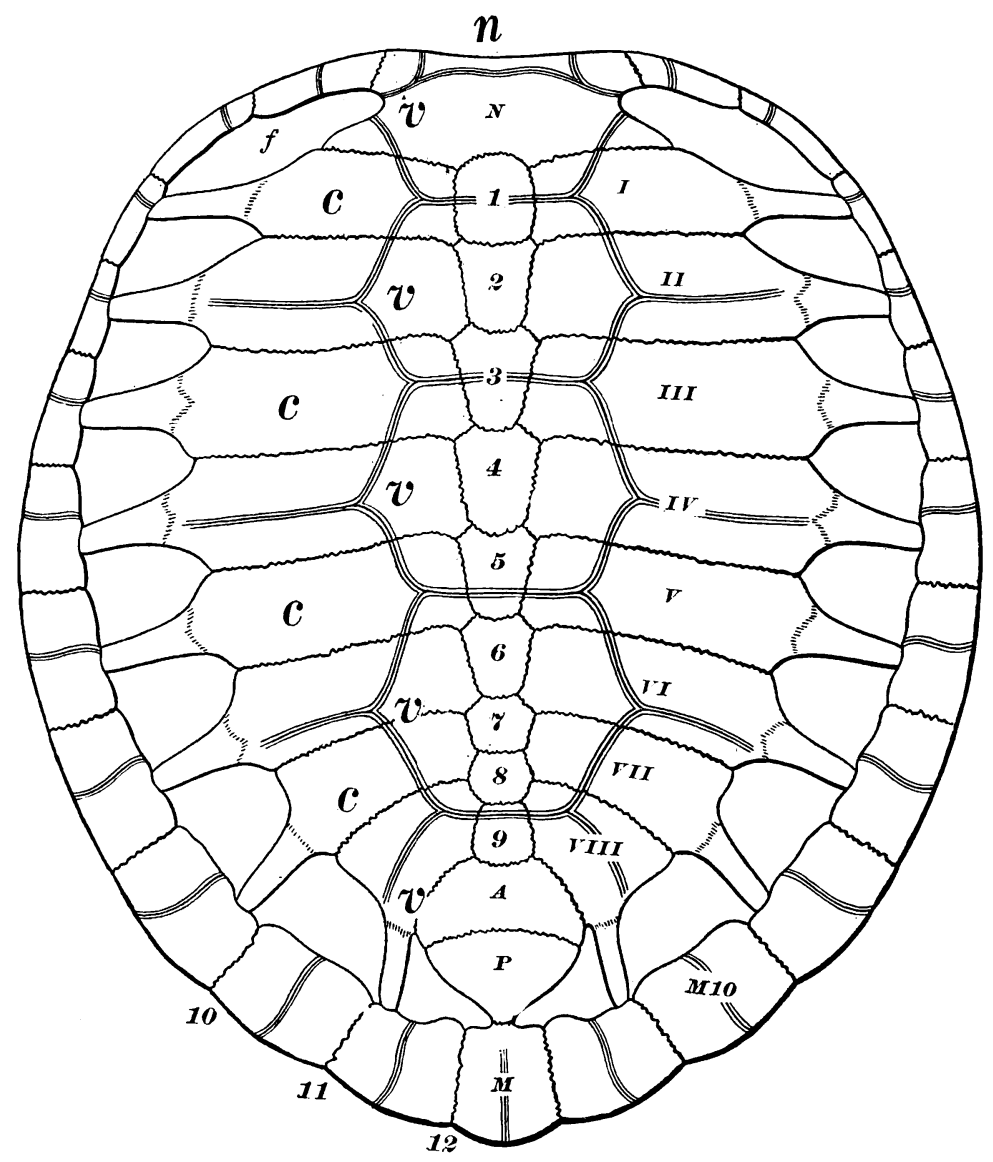

Carapace of Lytoloma angusta. $\times$ about $\frac{1}{5}$. Drawn from the specimen shown in the following Plate, VII. 


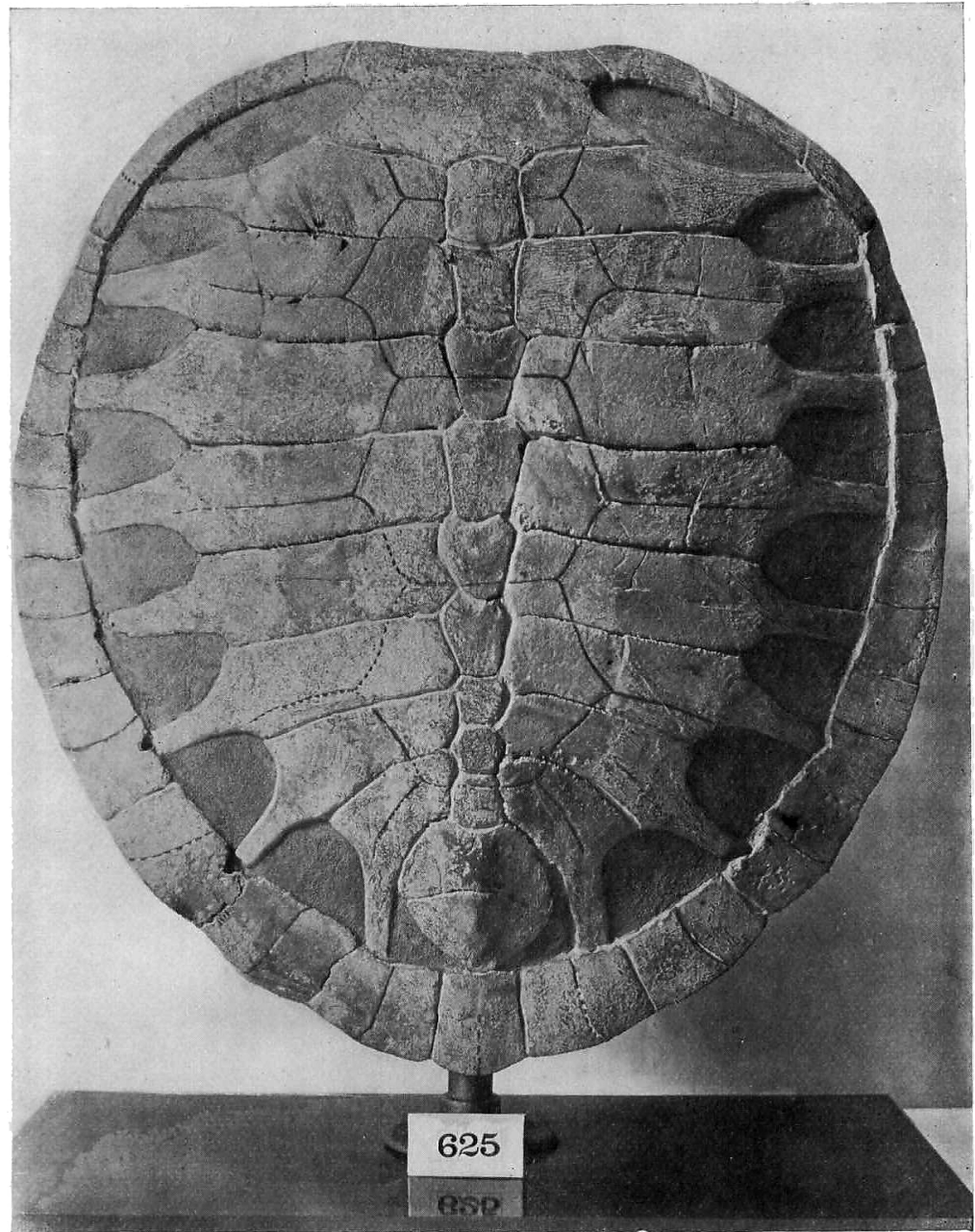

Carapace of Lytoloma angusta from the Upper Cretaceous Greensand of Barnsboro, Gloucester Co., New Jersey, as partly restored and mounted in the Yale Museum.-See Plate VIII. Actual length of Carapace about $58 \mathrm{~cm}$. 


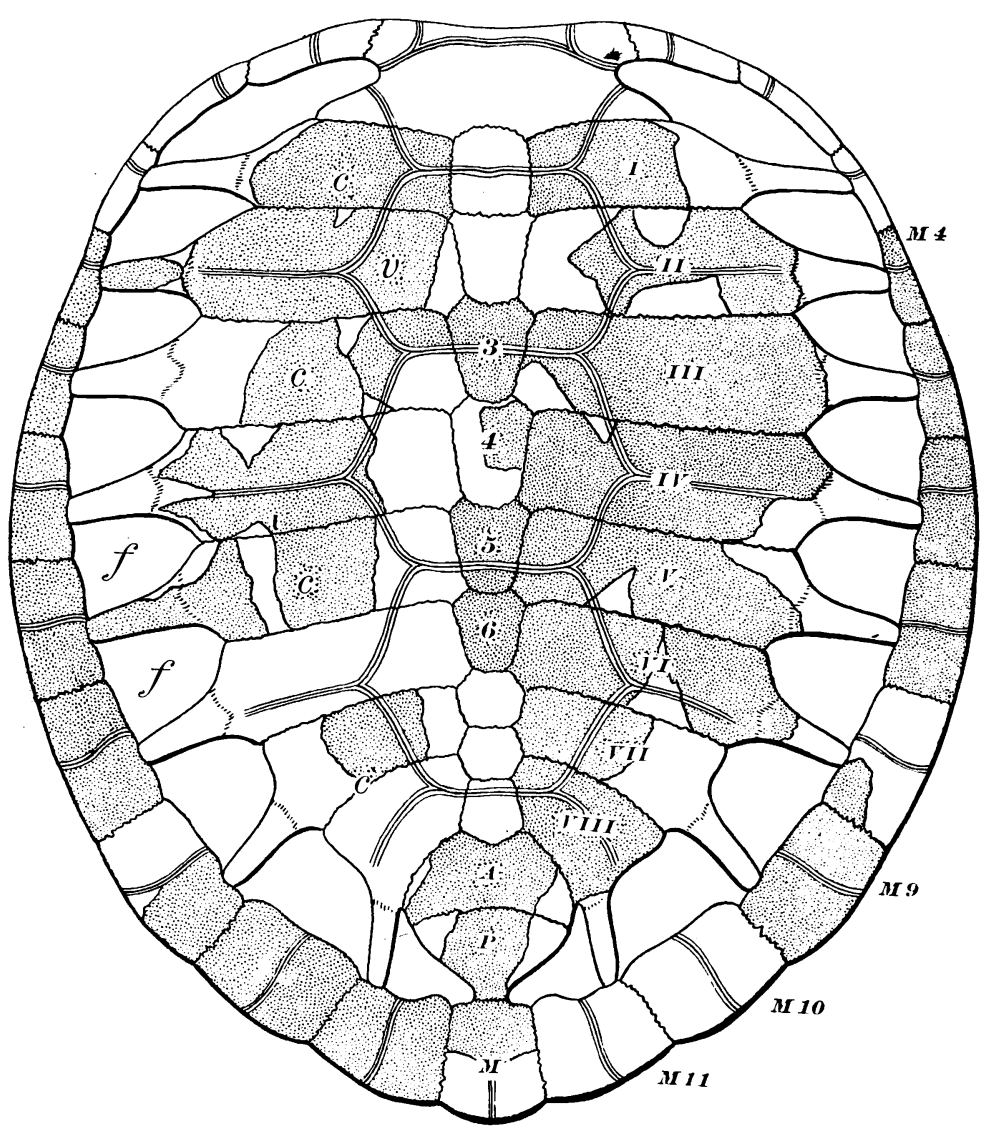

Carapace of Lyfoloma angusta. $\times$ about $\frac{1}{5}$. Diagrammatic figure. The stippled surfaces show the parts of the original speeimen as recovered in a disarticulated and more or less broken condition. See Plates VI and VII. 